\title{
THE AUTONOMY OF EU LAW: A HARTIAN VIEW
}

\author{
Justin Lindeboom $*$ 回
}

This article aims to reconstruct and theorise the autonomy of the European Union (EU) legal system by drawing on Hartian legal theory. It comprises four claims. First, the European Court of Justice's (ECF) 'foundational case law' on autonomy - and direct effect and supremacy as its corollaries - is conceptualised as a second-order thesis about the genus to which EU law belongs (the 'autonomy thesis'). Second, the ECf's reliance on the full effectiveness of EU law as a justification for the autonomy thesis alludes to the deep connection between legality and effectiveness, but this connection cannot rationally explain the normativity of the autonomy thesis as an internal statement of law. Third, in order to provide such an explanation, the autonomy thesis is reconceptualised as an 'internal recognitional statement' by which the ECF asserts a normative formulation of an autonomous EU rule of recognition. Fourth, within this Hartian analysis of the EU legal system, the doctrines of direct effect and supremacy lack self-standing analytical value. This article finishes with some very preliminary observations on a well-known objection against the autonomy of EU law based on the attitudes and perspectivism of national courts.

Keywords: EU law, autonomy, effet utile, HLA Hart, legal philosophy, transnational legal theory

\section{TABLE OF CONTENTS}

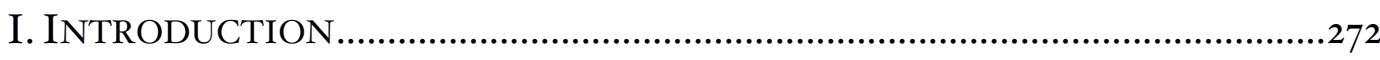

II. From TELEOLOGICAL INTERPRETATION TO THE AUTONOMY THESIS... 276

III. From EFFECTIVENESS TO THE INTERNAL POINT OF VIEW ...................... 282

I. The Role of Direct Effect and Invocability in the ECF Case Law ......................284

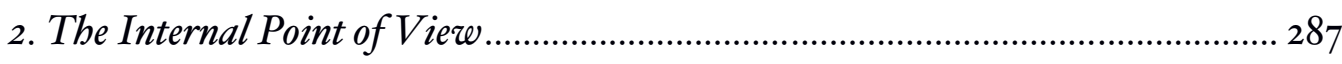

IV. HOW TO RECOGNISE 'A NEW LEGAL ORDER' ........................................... 288

Assistant Professor of Law, University of Groningen. I wish to thank David Dyzenhaus, Kostiantyn Gorobets, Dimitry Kochenov, Teng Li, Lorenzo Squintani, Kevin Toh, Bosko Tripkovic, Meir Yarom, Matthijs van Wolferen, and two anonymous reviewers for helpful comments on earlier drafts. The usual disclaimer applies. 
I. Van Gend \& Loos as an Internal Recognitional Statement .289

2. Pitching the Rule of Recognition: The Case of General Principles of EU Law ... 293

V. THE AUTONOMY THESIS AND THE DOCTRINES OF DIRECT EFFECT AND SUPREMACY .296

I. A Master Secondary Rule: The Doctrine of Direct Effect 297

2. Taking Norms Seriously: The Doctrine of Supremacy 300

3. Some Preliminary Remarks About Perspectivism and National Courts 303

VI. CONCLUSION 306

\section{INTRODUCTION}

Since the early I960s, the European Court of Justice (ECJ) ${ }^{\mathrm{I}}$ has claimed that the EU Treaties constitute an autonomous legal system ${ }^{2}$ whose justiciable norms are directly effective and have primacy - or supremacy ${ }^{3}$ - over conflicting national law. ${ }^{4}$ National administrative and judicial institutions are obligated to apply these norms. ${ }^{5}$ The constitutionalisation of the EU Treaties, most notably associated with van Gend \& Loos and Costa v ENEL, ${ }^{6}$ has been abundantly analysed from the perspective of legal hermeneutics, ${ }^{7}$

Since the Treaty of Lisbon, the official name of the European Court of Justice is 'Court of Justice of the European Union', which comprises both the General Court and the Court of Justice (informally still known as the 'European Court of Justice'). For considerations of simplicity and consistency, in this article I use the historic term 'European Court of Justice' (ECJ) throughout. By 'European Court of Justice' I refer to the highest judicial institution of the European Union. This article does not contain references to judgments of the General Court or the former Court of First Instance.

2 Recently, Opinion 2/13 EU:C:2014:2454, paras I66-I70; Opinion I/I7 EU:C:2019:34I, paras IO9-III.

3 I consider the terms 'primacy' and 'supremacy' as synonymous for the reasons set out in section V.2. below.

4 On direct effect, see recently e.g. Case C-573/17 Poptareski EU:C:2019:530. On primacy, see recently e.g. Case C-399/II Melloni EU:C:2013:IO7.

$5 \quad$ E.g. Case C-348/15 Stadt Wiener Neustadt EU:C:2016:882.

6 Case 26/62 van Gend \& Loos EU:C:1963:I; Case 6/64 Costa v ENEL EU:C:1964:66.

7 E.g. Hans Kutscher, 'Methods of Interpretation as Seen by a Judge at the Court of Justice' in Reports of a fudicial and Academic Conference held in Luxemburg on 2728 September 1976, 29-35; Pierre Pescatore, 'Van Gend en Loos, 3 February 1963 - A 
transformative constitutionalism, ${ }^{8}$ in a recent 'historical turn' in EU legal studies, ${ }^{9}$ and in historical studies. ${ }^{\circ}$

Nevertheless, the foundations of EU law as a transnational system of legal norms remain elusive. It is unclear to what extent the ECJ's claims regarding EU law's autonomy, and direct effect and supremacy as its corollaries, are theoretically explicable. Philosophers and theorists of law, however, generally have had little interest in the EU legal system. ${ }^{\text {II }}$ As a result, the fact that the EU's founding Treaty was signed over sixty years ago notwithstanding, there is no robust explanation of the ECJ's claims regarding the autonomy of the EU legal system.

The aim of this article is to offer an explanation of the ECJ's foundational case law on the autonomy of EU law, as well as the relevance of effectiveness

View from Within' in Miguel Poiares Maduro and Loïc Azoulai (eds), The Past and Future of EU Law (Hart 2010) 6; JHH Weiler, 'Rewriting Van Gend en Loos: Towards a Normative Theory of ECJ Hermeneutics' in Ola Wiklund (ed), Fudicial Discretion in European Perspective (Kluwer 2003). JHH Weiler, 'The Transformation of Europe' (1991) Ioo Yale Law Journal 2403. See e.g. the special issues (2OI2) 2I Contemporary European History; and (2013) 28 American University International Law Review; and Fernanda Nicola and Bill Davies (eds), EU Law Stories (Cambridge University Press 20I7). See e.g., Morten Rasmussen, 'Revolutionizing European Law: A History of the Van Gend \& Loos Judgment' (2OI4) I2 International Journal of Constitutional Law I36; Antoine Vauchez, 'The Transnational Politics of Judicialization. Van Gend \&o Loos and the Making of EU Polity' (2010) I6 European Law Journal I.

II For notable exceptions, see Joxerramon Bengoetxea, The Legal Reasoning of the European Court of Fustice (Clarendon Press 1993) (which provides a theory of the ECJ's legal reasoning based on institutional positivism); George Letsas, 'Harmonic Law' (offering a Dworkinian critique of EU constitutional pluralism) and Julie Dickson, 'Towards a Theory of European Union Legal Systems' (theorising the relationship between EU and national law from a legal systems perspective) both in Julie Dickson and Pavlos Eleftheriadis (eds), Philosophical Foundations of EU Law (Oxford University Press 20I2); Neil MacCormick, Questioning Sovereignty (Oxford University Press 1999) (analysing transnational legality from an institutional positivist theory); M.L. Jones, 'The Legal Nature of the European Community: A Jurisprudential Analysis using HLA Hart's Model of Law and a Legal System' (1984) I7 Cornell International Law Journal I (offering an early and somewhat coarse-ground analysis of the EU legal system based on Hart's legal theory). 
in this respect, which tries to remain faithful to EU law's self-understanding and describes it in its own terms. ${ }^{\mathrm{I}}$ In order to do so, the central question of this article is whether we can conceptualise this foundational case law in the vocabulary of HLA Hart's seminal theory of law and recent elaborations thereupon. The choice for Hartian legal theory - rather than, say, Kelsen's or Dworkin's - is in part purpose-driven, as I believe it can accurately account for the existence and structure of the EU legal system. ${ }^{13}$ However, arguably this choice is also warranted on other grounds. In contemporary legal philosophy, Hart's work remains profoundly influential and many philosophers consider it unrivalled in its account of the circumstances under which communities are governed by a legal system. ${ }^{14}$ Secondly, Hart explicitly centred his theory of law on the idea of separate legal systems - as opposed to Kelsen's monistic theory of law, among others - which makes his work at least prima facie suitable for the analysis of the ECJ's construction of EU law as a legal system separate from national legal systems. ${ }^{15}$

As I hope to show, Hartian legal theory, and analytical jurisprudence in general, is of much added value to EU constitutionalism, which tends not to make use of the insights of analytical jurisprudence - a socially obligatory reference to The Concept of Law aside. Alas, Hart's work 'is known as much by

I2 Theoretical accounts of EU law usually apply extra-legal vocabularies, mainly those from political science. This is exemplified by characterisations of EU law that rely on concepts such as federalism, supranationalism and intergovernmentalism, multi-level governance, etc. This article tries to avoid such 'foreign' vocabulary. I could also say that I am trying to offer a purely legal theory of EU law, but that would be misleading because I am relying mainly on Hartian and post-Hartian legal theory, which rejects Kelsen's metaphysical and methodological commitments to a pure theory of law.

I3 I alluded to this point in Justin Lindeboom, 'Why EU Law Claims Supremacy' (2018) 38 Oxford Journal of Legal Studies 328.

I4 This is not to deny or belittle important criticisms of Hart's work by positivists (e.g. Joseph Raz, John Gardner, and Scott Shapiro), anti-positivists (e.g. Ronald Dworkin and Robert Alexy) and natural lawyers (e.g. John Finnis). The phrasing 'the circumstances [...] legal system' is to indicate that I understand Hart's theory of the characteristics of the legal system as an explanation from the external point of view, and in that respect its key tenets are still widely accepted.

is Case 13/6I Bosch and van Rijn EU:C:I962:II. 
rumour as by reading', as Leslie Green observes in his introduction. ${ }^{16}$ This is not to pretend that my choice for Hart's legal theory as such is original. While most accounts on the supposed autonomy of EU law at most only allude to Hart's work without deeper engagement, ${ }^{17}$ Barber and Letsas's analyses of European constitutional pluralism brilliantly draw on Hartian and postHartian theory of the legal system and the notion of the rule of recognition. ${ }^{\text {I8 }}$ More generally, the relationship between national and EU law has also attracted the interest of legal philosophers including MacCormick, ${ }^{19}$ Eleftheriadis, ${ }^{20}$ and Dickson. ${ }^{21}$ However, what has been missing from the literature is a Hartian account of the autonomy of EU law from the latter's own self-understanding, as reflected in the ECJ's foundational case law on autonomy, direct effect, and supremacy. ${ }^{22}$ This, then, is the purpose of this article.

The remainder of this article is structured as follows. Section II will set the scene by questioning the 'common story' of van Gend \& Loos and the founding of the EU legal system as an exercise in teleological interpretation. Following Alexander Somek's claim that in constitutionalising the EU Treaties, 'the Court inferred the legal form of Community law from its content', ${ }^{23}$ I will argue that the legal form that the EU Treaties have been understood to

I6 HLA Hart, The Concept of Law (3rd edn, Oxford University Press 2012) xv.

${ }_{17}$ E.g. Teodor Schilling, 'The Autonomy of the Community Legal Order: An Analysis of Possible Foundations' (1996) 37 Harvard International Law Journal $389,398$.

I8 NW Barber, 'Legal Pluralism and the European Union' (2006) I2 European Law Journal 306; Letsas (n II). Neil MacCormick, 'The Maastricht-Urteil: Sovereignty Now' (1995) I European Law Journal 259; MacCormick (n II).

20 E.g. Pavlos Eleftheriadis, 'Aspects of European Constitutionalism' (I996) 2I European Law Review 32; and 'Pluralism and Integrity' (2010) 23 Ratio Juris 365.

${ }^{21} \quad$ Dickson (n II)

22 Thus, I take the ECJ's case law to 'speak on behalf of the law', as it were. Obviously, one may distinguish between 'the law' and 'what courts say is the law'. While the anthropomorphisation of 'the law', and the role of courts therein, is worth a discussion of its own, I leave that point aside here.

23 Alexander Somek, 'Is Legality a Principle of EU Law?' in Stefan Vogenauer and Stephen Weatherill (eds), General Principles of Law: European and Comparative Perspectives (Hart 20I7) 67. 
possess since van Gend \& Loos is that of an autonomous legal system. I describe this argument as the 'autonomy thesis'. This autonomy thesis is the central object of analysis in the subsequent sections.

Section III explores the relationship between the autonomy thesis and what the ECJ considers its central rationale, the principle of effectiveness. Effectiveness is a necessary condition of legality, but it cannot be the reason for legality, nor can it account for the fact that the ECJ expresses the autonomy thesis as a normative statement. To understand the foundational case law, we need an 'internal point of view', in Hart's words.

Section IV proceeds accordingly by conceiving van Gend \& Loos and Costa $v$ ENEL as internal formulations of an EU rule of recognition, and uses the development of general principles of EU law as an example of how the ECJ has tried to 'pitch' the EU legal system towards national courts.

Rephrasing the autonomy thesis in Hartian vocabulary invites a conceptualisation of the two other doctrines central to the ECJ's foundational case law: direct effect and supremacy. Section $\mathrm{V}$ reconfigures the salience of direct effect and supremacy as elements of the 'union of primary and secondary rules' that Hart deemed central to the concept of a legal system. This section ends with some very preliminary observations on scepticism about the autonomy of EU law, which is based on the perspectivism of national (constitutional) courts, and aims to presage further, jurisprudentially informed, research to this end. Section VI concludes.

\section{FROM TELEOLOGICAL INTERPRETATION TO THE AUTONOMY THESIS}

It seems almost commonplace to perceive the Court's foundational case law as an example of teleological interpretation. ${ }^{24}$ Van Gend \& Loos remains the paradigmatic case, as the Court here infers autonomy and direct effect from the spirit and general scheme of the Treaty. This kind of purposive interpretation of the Treaties and secondary legislation has been both hailed as a noble dream, 'well developed [...] and presented to individuals and their

${ }_{24} \quad$ See e.g., Bengoetxea (n II) 250-258; Mitchel Lasser, Fudicial Deliberations (Oxford University Press 2004) 207; Gunnar Beck, The Legal Reasoning of the Court of fustice of the European Union (Hart 2013) 207-2I2. 
judges with such elegance and persuasive power', ${ }^{25}$ and despised as a nightmare, ${ }^{26}$ or a juridical coup d'état. ${ }^{27}$ Many authors understand the Court's case law as an example of what has come to be known as 'meta-teleological interpretation'. First introduced by Lasser, ${ }^{28}$ and subsequently used by Poiares Maduro and Conway, ${ }^{29}$ the concept of 'meta-teleological interpretation' refers to the interpretation of individual legal norms in light of the purposes of the legal system as a whole. ${ }^{30}$ Even if 'meta-teleological' interpretation statistically does not play a major role in the Court's jurisprudence, ${ }^{3 \mathrm{I}}$ it has had considerable influence in the Court's landmark judgments. ${ }^{32}$

However, in a recent contribution, Alexander Somek claimed not only that the reasoning in van Gend \& Loos is illegitimate, but also that it cannot even count as teleological interpretation in the first place. What is important in this regard is that the revolutionary impact of van Gend $\&$ Loos was not that article 12 of the Treaty establishing the European Economic Community (EEC) had direct effect, as Weiler and de Witte had indeed already demonstrated. ${ }^{33}$ The key contribution of van Gend $\&$ Loos is that the question of whether EU norms have direct effect must solely be answered by EU law

\footnotetext{
${ }_{25} \quad$ Pescatore (n 7$)$.

26 For the classical critique, see Hjalte Rasmussen, On Law and Policy in the European Court of fustice (Martinus Nijhoff I986).

27 Alec Stone Sweet, 'The Juridical Coupd'État and the Problem of Authority' (2007) 8 German Law Journal 915.

$28 \quad$ Lasser (n 24) 206-215, 359 .

29 Miguel Poiares Maduro, 'Interpreting European Law: Judicial Adjudication in a Context of Constitutional Pluralism' (2007) I(2) European Journal of Legal Studies I; Gerard Conway, 'Levels of Generality in the Legal Reasoning of the European Court of Justice' (2008) I4 European Law Journal 787.

$30 \quad$ Lasser (n 24) 208; Poiares Maduro (n 29) I2-I4.

${ }^{31} \quad$ Sibylle Seyr, Der effet utile in der Rechtsprechung des EuGH (Duncker \& Humblot 2008) 270, notes that out of 455 judgments containing effet utile - or purpose-based interpretation, more than $63 \%$ pertain to the effectiveness of the individual legal norm, rather than that of the EU legal system as a whole.

32 See e.g. Urška Šadl, 'The Role of Effet Utile in Preserving the Continuity and Authority of European Union Law' (2015) 8 European Journal of Legal Studies I8.

33 The result might well have been the same under public international law: Weiler (n 7$)$.
} 
itself: autonomy, not direct effect as such. ${ }^{34}$ By declaring the irrelevance of the monistic and dualistic systems of incorporation in national constitutional law, the Court emancipated EU law from public international law. The latter lacks a doctrine of 'internal primacy' to this day. ${ }^{35}$ Further, in contrast to public international law - under which the Treaty of Rome would be part of the general system of international law - van Gend \& Loos and Costa v ENEL purported to create an EU legal system that governs its own jurisdiction. The Court thus expressly dissociated the EU legal system from public international law. ${ }^{36}$ Somek takes these well-known facts to their logical implication: the 'myth of teleological interpretation' disguises the fact that 'the Court inferred the legal form of Community law from its content'. ${ }^{37}$ As I understand his argument, 'legal form' refers to the form of an autonomous legal system, which operates normatively separately from national legal systems and international law.

Somek is right to conclude that teleological interpretation is an unconvincing explanation of the Court's foundational case law. Teleological interpretation is a method of interpretation locating the content of individual legal norms or perhaps sets of legal norms - in their purpose. Meta-teleological interpretation shifts focus to the purpose of the entire legal system, but it is still concerned with the process of discovering the content of some norm or set of norms.

In stark contrast, the autonomous nature of the EU legal system as inferred from the Treaty's substance in van Gend \& Loos, is not an interpretation of any legal norm in particular. It is rather a second-order interpretation of the genus

34 Somek (n 23) 67; Bruno de Witte, 'Direct Effect, Supremacy, and the Nature of the Legal Order' in Paul Craig and Gráinne de Búrca (eds), The Evolution of EU Law (Oxford University Press 20I2).

35 Bruno de Witte, 'The Continuous Significance of Van Gend en Loos' in Miguel Poiares Maduro and Loïc Azoulai (eds), The Past and Future of EU Law (Hart 20IO). See further e.g. Thomas Buergenthal, 'Self-Executing and Non-SelfExecuting Treaties in National and International Law' in (1992) 235 Collected Courses of the Hague Academy of International Law 303.

${ }^{36}$ This is why I consider conceptions of EU law as part of some general system of international law unpersuasive. Cf. e.g. Derrick Wyatt, 'New Legal Order, or Old?' (I982) 7 European Law Review I47.

37 Somek (n 23) 67. 
to which the Treaty belongs: not a treaty in public international law, but an autonomous legal system. ${ }^{38}$ Rather than interpreting any EU norm, the Court appears to take an outsider's perspective by observing the form of the Treaty of Rome. This difference between interpreting the Treaty's form and interpreting the Treaty's legal norms is visible in the structure of van Gend \& Loos itself: only after introducing the doctrine of direct effect as a corollary of autonomy does the Court discuss whether article I2 EEC possesses direct effect, and to that end it introduces the criteria of sufficient clarity and unconditionality. Both direct effect and supremacy are not - and could not possibly be - inferred from any legal norm. ${ }^{39}$

I will refer to the ECJ's conception of the EU Treaties - introduced in van Gend \& Loos and Costa $v$ ENEL and maintained up to Opinions $2 / I_{3}$ and I/I as the 'autonomy thesis'. The autonomy thesis comprises two elements. The first element, already mentioned, is that EU law is a self-referential legal system that cannot be known from an external Archimedean vantage point. ${ }^{\circ}$ In Hartian parlance, EU law has its own rule of recognition. ${ }^{4 \mathrm{I}}$

$3^{8} \quad$ By 'second-order interpretation' I mean an interpretation of the form of the activity in which interpretation of first-order norms takes place. Second-order interpretation is accordingly distinct from 'meta-teleological interpretation', which is a specific method of interpreting first-order norms. To provide an analogy: interpreting first-order norms of etiquette should be distinguished from interpreting the 'activity' of etiquette as such, e.g. by asking how etiquette is different from other normative systems, whether etiquette is conventional, etc. This makes it somewhat odd that some scholars have expressed surprise that the doctrines of autonomy and supremacy cannot be found in the Treaty. See recently e.g. Thomas Horsley, The Court of fustice of the European Union as an Institutional Actor: Fudicial Lawmaking and its Limits (Cambridge University Press 2018) II5I3I. Even if this were the case, this begs the question why this supremacy rule, as a rule of the Treaty, would have supremacy over the manner in which national constitutional law regulates the incorporation of public international law. No first-order supremacy rule in the EU Treaties could of itself generate the supremacy (or, mutatis mutandis, autonomy) of the EU legal system.

40 See Gunther Teubner, "'And God Laughed...": Indeterminacy, Self-Reference, and Paradox in Law' in Christian Joerges and David Trubek (eds), Critical Legal Thought (Nomos 1989).

4r See Lindeboom (n I3); Koen Lenaerts and José A Gutiérrez-Fons, 'A Constitutional Perspective' in Robert Schütze and Takis Tridimas (eds), Oxford 
The second element of the autonomy thesis pertains to the nature of the rule of recognition. According to Hart, a rule of recognition is practiced by a subset of the members of the community he calls 'legal officials' ${ }^{42}$ Contrary to public international law, the autonomy thesis entails that national administrative and judicial authorities become legal officials of the EU legal system. The EU legal system speaks directly to national authorities by obligating them to apply EU law. ${ }^{43}$ From the perspective of Hartian legal theory, the relationship between system and official is a more fundamental cornerstone of the legal system than the one between system and individual, which has been the focus of most scholarship on the constitutionalisation of the EU Treaties. ${ }^{44}$

This second element of the autonomy thesis may generate puzzlement as it applies to national legal officials notwithstanding their constitutional and institutional entrenchment in their domestic legal systems. However, similar puzzlement about the Hartian concept of legal official transcends the specific case of EU law's autonomy thesis. For Hart, legal officials create a legal system by committing to its rule of recognition. Responding to the apparent circularity and indeterminacy of this reasoning, ${ }^{45}$ the genealogy of

Principles of European Union Law. Volume I: The European Union Legal Order (Oxford University Press 2018).

42 Hart (n I6) 90-99.

43 As to national courts, see e.g. Case 106/77 Simmenthal EU:C:1978:49; Case C213/89 Factortame EU:C:1990:257; and Case C-416/ıo Križan EU:C:2012:218. As to national administrative authorities, see e.g. Case I03/88 Fratelli Costanzo EU:C:1989:256.

44 Cf. e.g. JHH Weiler, 'Van Gend en Loos: The Individual as Subject and Object and the Dilemma of European Legitimacy' (2014) I2 International Journal of Constitutional Law 94. Hart's discussion about the necessary and sufficient conditions for the existence of legal systems requires, on part of the broader community of individuals, only general obeyance for any motive whatever. Only the subset of 'legal officials' needs to practice the rule of recognition, which they do by accepting it as 'common public standards of official behaviour' (Hart (n I6) II6).

45 As to circularity, legal officials such as courts derive their identity as officials from the law. At the same time, they are said to constitute the legal system. As to indeterminacy, Hart's theory does not make clear which subset of a community's members are supposed to count as legal officials as opposed to officials of any other normative system. This relates also to the over-inclusiveness of Hart's 
legal systems presumes that some powerful subset of the members of a community - call them 'proto-officials' - may start regarding themselves as being bound by some set of rules, perhaps even mistakenly or accidentally, and in doing so begin constituting a legal system. ${ }^{46}$ Thus the proto-officials of system A can transform into genuine officials of system A, and officials of system A can transform into the proto, then actual officials of system $B$.

Thus, as applied to EU law, circularity and indeterminacy do not pose any theoretical problems because the ECJ never communicated with a random subset of the members of the population. ${ }^{47}$ The role of national courts as legal officials of their national legal systems makes them sufficiently determinable as a sociological category of proto-officials of the EU legal system. ${ }^{4}$ The autonomy thesis is anti-institutional in purporting to transform the identity of national courts, while recognising their current institutional position; an exercise in symbolic power par excellence, to use Bourdieu's terminology. ${ }^{49}$

To sum up, the Court's foundational case law on the autonomy, direct effect and supremacy is inaptly described as a teleological interpretation of the legal norms of the EU Treaties. Instead, the autonomy thesis is a thesis about the form that the EU Treaties have created. It states that EU law is identified by its own rule of recognition, and that all Member State authorities are legal officials of the EU legal system..$^{\circ}$

The remainder of this article will try to flesh out the logic of the autonomy thesis. If the autonomy thesis is not an interpretive statement about the

theory of legal system: Keith Culver and Michael Giudice, Legality's Borders (Oxford University Press 2010) IO-2I. Hart (n I6) III-I23; John Gardner and Timothy Macklem, 'Review of Scott J. Shapiro, Legality' [20II] Notre Dame Philosophical Reviews <https://ndpr.nd. edu/news/legality/> accessed I8 August 2020. For alternative, though related, solutions to the circularity paradox, see Culver and Giudice (n 45) IO-I4. Art 267 TFEU refers to 'any court or tribunal of a Member State'.

48 Koen Lenaerts speaks in this regard of 'national judges as the arm of EU law (or, put more simply, as "European judges")': Koen Lenaerts, 'Upholding the Rule of Law through Judicial Dialogue' (2019) 38 Yearbook of European Law I, 4 (emphasis in original).

49 Pierre Bourdieu, 'The Force of Law: Toward a Sociology of the Juridical Field' (I987) 38 Hastings Law Journal 805, 839.

5० See further Section IV below. 
normative substance of EU norms, what kind of statement is it? Can it be explained at all, or should we simply take the Court's case law for granted, whether or not we believe in its legitimacy? In the next section, I will start by looking at the Court's effectiveness argument, which takes centre stage in the autonomy thesis: that the effectiveness of EU law can only be guaranteed if EU law governs its own application, and is directly applied by Member State authorities.

\section{FROM EFFECTIVENESS TO THE INTERNAL POINT OF VIEW}

From van Gend of Loos to Opinion 2/13, the ECJ has largely justified the autonomy thesis by reference to the need to ensure the effectiveness of the EU Treaties. ${ }^{5 \mathrm{I}}$ But while effectiveness is an empirical measurement, court decisions are interpretations of norms and are therefore normative themselves. The logic of the ECJ's foundational case law must therefore account for both its normative character and the central role of effectiveness. In order to flesh out this dynamic, we need a small detour towards the relationship between effectiveness and legal validity, before returning to autonomy in section IV.

It is widely established in legal theory that some degree of effectiveness is a necessary condition for the validity of law. No 'legal system purport' is valid law if it is not effectively upheld..$^{2}$ The precise relationship between effectiveness and legal validity has been extensively analysed in the work of

51 Case 26/62 van Gend \& Loos EU:C:I963:I: 'the vigilance of individuals [...] amounts to an effective supervision in addition to the supervision entrusted by articles 169 and I70 [...]'; Opinion 2/13 EU:C:2014:2454, paras I88-189, 197.

52 Hans Kelsen, General Theory of Law and State (Anders Wedberg tr, Harvard University Press I945) II9; Hart (n I6) II6-II7; Joseph Raz, The Concept of a Legal System, (2nd edn, Clarendon Press 1980) 202-207; Ralf Dreier, 'Der Begriff des Rechts' (1986) 39 Neue Juristische Wochenschrift 890, 896; Robert Alexy, Begriff und Geltung des Rechts (Karl Alber 1992) 20I. Even Dworkin's anti-positivist conception of law as integrity is grounded in the imperative of interpreting the posited legal materials as much as possible as part of one coherent political morality. As Dworkin puts it, legal claims should have 'institutional support' (Ronald Dworkin, 'The Model of Rules I' reprinted in Taking Rights Seriously (Harvard University Press I978)) and social facts exercise a 'gravitational force' on legal content (Ronald Dworkin, 'Hard Cases' reprinted in ibid). 
Hans Kelsen, on which Hart appears to rely heavily (but mostly silently). For Kelsen, validity can be equated to existence: to say that a legal norm is valid is tantamount to saying that it exists, and vice versa. ${ }^{53}$ Given that validity is the only quality that legal norms possess, the effectiveness of legal norms must be an extra-legal quality. Statements about the effectiveness of legal norms thus pertain to people's actual observance of the legal norms. ${ }^{54}$

For Kelsen, the link between effectiveness and validity is established through the presupposition of the Grundnorm. This presupposition must be conditional upon the overall effectiveness of the legal system; in other words, a legal system that is by and large effective is a condition for presupposing the Grundnorm, which validates all other legal norms. ${ }^{55}$ However, in order to maintain his epistemic and metaphysical distinction between the factual ('Sein') and the normative ('Sollen'), Kelsen repeatedly stresses that effectiveness is only a negative condition for validity:

The efficacy of the entire legal order is a necessary condition for the validity of every single norm of the order. A conditio sine qua non, but not a conditio per quam. The efficacy of the total legal order is a condition, not the reason for the validity of its constituent norms. ${ }^{56}$

Even individual legal norms can lose their legal validity, notwithstanding the legal system's overall efficacy, if they remain permanently inefficacious. While the validity of newly enacted legal norms is provided by a higher-order

53 Hans Kelsen, The Pure Theory of Law (Max Knight tr, University of California Press 1967) IO; Joseph Raz, The Authority of Law (Clarendon Press I979) I46.

$54 \quad$ Kelsen (n 52) 39-40.

55 Ibid $4 \mathrm{I}-42$, II9.

56 Ibid II9. A terminological note: In Reine Rechtslebre, Kelsen mainly used the word 'Wirksamkeit' in this context, which is usually translated as 'efficacy' rather than 'effectiveness' in part because Kelsen also employs the term 'Effektivität' in a seemingly different manner. I use 'effectiveness' and 'efficacy' interchangeably here because my point is precisely that what Kelsen calls 'Wirksamkeit' and 'efficacy' (as does Hart, see III.2. below) is relevant to the role of what in EU law is usually called '(full) effectiveness' or 'effet utile'. 
norm - making them valid before there are first observed or applied - '[a] legal norm is no longer seen as valid if it remains permanently inefficacious'. ${ }^{57}$

Building on Kelsen's framework, Joseph Raz elaborated that effectiveness in the sense of obedience to the laws is hardly a measurable criterion for the existence of a legal system. After all, '[h]ow should cases of disobedience be counted? [...] How many opportunities not to murder does one have during a year? And how many opportunities not to steal?'.$^{8}$ Raz proposes instead to focus on the recognition of legal norms by law-applying institutions. ${ }^{59} \mathrm{He}$ claims that such recognition is a necessary condition of their existence by way of counterfactual: the question is whether the courts would apply a norm if they were presented with an appropriate case for applying it. ${ }^{60}$ Very similarly, Eugenio Bulygin conceives of effectiveness as a situation in which, provided that the necessary conditions for applying a norm obtain, courts will apply the norm. The effectiveness of legal norms thus correlates with their invocability before courts. ${ }^{6 r}$

\section{The Role of Direct Effect and Invocability in the ECF Case Law}

Raz's and Bulygin's formulation of the effectiveness-validity nexus already gives us a hint of the relevance of the Court's case law on the direct effect of EU law. Direct effect is the key mechanism for the EU legal system to guarantee its enforceability. In the words of Pescatore,

[a]ny legal rule is devised so as to operate effectively (we are accustomed, in French, to speak here about effet utile). If it is not operative, it is not a rule of law [...] In other words, practical operation for all concerned, which is

$57 \quad$ Hans Kelsen, 'Validity and Efficacy of the Law' (Bonnie Litschewski Paulson and Stanley Paulson trs), in Eugenio Bulygin, Essays in Legal Philosophy (Carlos Bernal and others eds, Oxford University Press 2015) 67.

$58 \quad \operatorname{Raz}\left(\mathrm{n}_{52}\right) 203$.

59 Ibid I9I-20I.

$60 \quad \operatorname{Raz}(\mathrm{n} 53) 87-88$.

6r Eugenio Bulygin, 'The Concept of Efficacy' (Bonnie Litschewski Paulson and Stanley Paulson trs), in Eugenio Bulygin, Essays in Legal Philosophy (Carlos Bernal and others eds, Oxford University Press 2015) 48-5I. 
nothing else than 'direct effect', must be considered as being the normal condition of any rule of law. ${ }^{62}$

As I understand Pescatore's claim, direct effect is not really a substantive doctrine of EU law, but rather a doctrinal restatement of its practical operation. Obviously, enforcement need not necessarily be within the Member States, and invocability need not necessarily be before national courts. A legal order of international law might well be effective at an international level only. But scepticism of the effectiveness and accordingly the legality of international law continues to this day. ${ }^{63}$ Thus, a charitable interpretation of Pescatore's observation is that the rules of the EU Treaties would not really be legal rules if they were not directly enforced in the domestic sphere.

The early development of the case law on the principle of effectiveness in the context of 'procedural autonomy' served a similar function to direct effect. ${ }^{64}$ According to the doctrine of procedural autonomy, pending the harmonisation of procedural rules at EU level, it is for the national legal orders to lay down the rules on legal procedures and remedies to which substantive claims based on EU law before national courts are subject. ${ }^{65}$ However, national procedural rules applying to claims based on EU law may not make the exercise of EU law rights 'virtually impossible' or 'impossible in practice', a principle which national courts are obligated to protect. ${ }^{66}$ This

62 Pierre Pescatore, 'The Doctrine of "Direct Effect": An Infant Disease of Community Law' (1983) 8 European Law Review I55 (1983), reprinted in (2015) 40 European Law Review 135 (subsequent citations refer to the 2015 reprinted version for convenience).

63 E.g. Jack Goldsmith and Eric Posner, The Limits of International Law (Oxford University Press 2005).

${ }^{64}$ In later years, the principle of effectiveness has accumulated more positive, hermeneutic content, which translates into more stringent requirements for national procedural law. For an overview of this development, Norbert Reich, 'The Principle of Effectiveness and EU Private Law' in Ulf Bernitz and others (eds), General Principles of EU Law and European Private Law (Intersentia 2013).

65 See generally, Michael Dougan, 'The Vicissitudes of Life at the Coalface' in Paul Craig and Gráinne de Búrca (eds), The Evolution of EU Law (Oxford University Press 20II).

Case 33/76 Rewe-Zentralfinanz EU:C:1976:I88, para 5; Case 45/76 Comet EU:C:I976:I9I, para I6. 
principle of effectiveness adds to the principle that national procedural rules may not discriminate between actions based on EU law and similar actions based on national law (the principle of equivalence or non-discrimination) ${ }^{67}$

Neither the doctrine of procedural autonomy, nor its limit in the principle of effectiveness, are found in the EU Treaties. These are not interpretations of first-order legal norms of EU law. ${ }^{68}$ The doctrine procedural autonomy rather guarantees that EU law norms can be enforced before national courts, as does direct effect itself. The principle of effectiveness in the case law on procedural autonomy gives normative expression to the factual observation that legal norms which cannot be invoked before courts, or which are not applied by courts when they are invoked, are insufficiently effective to retain their legal validity.

However, this legal-theoretical appraisal of effectiveness remains incapable of describing the normative logic of the autonomy thesis. In other words, we require an understanding of van Gend \& Loos's normative point of view which takes sufficient account of the factual salience of effectiveness, without reducing the judgment to a factual statement about effectiveness. Avoiding such reductionism is crucial not only because court judgments necessarily are normative statements about what the law requires, but also because if van Gend \& Loos were a descriptive, factual statement, it would obviously be wrong: the doctrines of autonomy and direct effect did not 'exist' before the ECJ proclaimed them. The vantage point of Hart's legal theory helps to grasp the normative logic of van Gend \& Loos.

67 Case 33/76 Rewe-Zentralfinanz EU:C:1976:I88, para 5; Case 45/76 Comet EU:C:1976:I91, para I3.

68 This may also be different for the more stringent interpretation of the principle of effectiveness established in later case law (see Reich (n 64)), which relies heavily on art 47 CFR. My analysis is confined to the foundational principles of procedural autonomy, which form the basis of the interaction between EU substantive law and national procedural law. Arguably, the principle of equivalence or non-discrimination as such could be seen as a cornerstone of the first-order substance of EU law, although the Treaties do not specifically apply it to national procedural rules. 


\section{The Internal Point of View}

Central to Hart's theory of law is the distinction between the internal and the external point of view, and the corresponding distinction between internal statements and external statements. An internal statement is a statement of some legal norm or its interpretation given by someone who is committed to the rule of recognition. ${ }^{69}$ Internal statements are therefore legal statements by those who are actively engaged in the legal system. External statements are statements by someone who merely observes the legal system and is not himself active within it. According to Hart, an external statement describes the fact that some people accept a given rule of recognition. ${ }^{70}$ Put differently, internal statements, or statements from the internal point of view, are statements of law. External statements, or statements from the external point of view, are statements about law..$^{71}$

Whether a legal system is effective is a question from the external point of view. For Hart, making internal statements about a legal system presupposes the general efficacy of that legal system:

One who makes an internal statement concerning the validity of a particular rule of a system may be said to presuppose the truth of the external statement of fact that the system is generally efficacious. For the normal use of internal statements is in such a context of general efficacy. ${ }^{72}$

Elsewhere, Hart refers to the 'context of general efficacy' as the 'normal context' of making internal normative statements about what the law is. ${ }^{73}$ This 'normal context' seems remarkably similar to Pescatore's observations that 'practical operation for all concerned [...] must be considered as being the normal condition of any rule of law', 'any legal rule must be at first sight

\footnotetext{
69 Hart (n I6) IO2-IO3.

70 Ibid Io3.

${ }^{71}$ For this formulation, see Kevin Toh, 'An Argument Against the Social Fact Thesis (and Some Additional Preliminary Steps Towards a New Conception of Legal Positivism)' (2008) 27 Law and Philosophy 445, 45I-452.

72 Hart (n I6) IO4 (emphasis in original).

73 HLA Hart, 'Scandinavian Realism' in Essays in Furisprudence and Philosophy (Clarendon Press 1983) I68.
} 
presumed to be operative in view of its object and purpose', and that '"direct effect" is nothing but the ordinary state of the law'. ${ }^{74}$

As a participant in the EU legal system, the ECJ necessarily adopts an internal point of view. In making statements on 'direct effect' and the necessity of facilitating the 'enforceability' of EU norms, however, the ECJ seems to make explicit the necessary preconditions for EU legality. This would amount to making an external statement about the existence of the EU legal system from within the system: i.e. an external statement disguised as an internal, normative statement. Admittedly, the ECJ locates part of its hermeneutics in the principle of loyalty in article 4(3) TEU.75 No individual norm, however, can serve as a basis for an external statement regarding the effectiveness of either that norm itself or its legal system. As the validity of the norm depends on its effectiveness, the norm can never be a reason for its own effectiveness. Pescatore is obviously right to argue that any legal norm in some way aspires towards achieving its aim in reality. However, this argument is unable to bootstrap an internal, normative statement from an external statement on efficacy.

Accordingly, to make sense of the doctrine of direct effect, and the autonomy thesis more generally, as normative statements, we need an understanding of the autonomy thesis as an internal statement. The next section will try to provide such an understanding by conceiving the autonomy thesis as a socalled internal recognitional statement, i.e. a normative expression of the rule of recognition of the EU legal system.

\section{HOW TO RECOGNISE 'A NEW LEGAL ORDER'}

This section will provide an explanation of the foundational case law using two central features of Hart's theory of law. The first was introduced in the previous section: the distinction between the internal and the external point of view. The second is Hart's theory of the legal system. For Hart, a central characteristic of a legal system is that it unites a system of primary and secondary rules identified by a certain law-identifying rule, which Hart calls

\footnotetext{
$74 \quad$ Pescatore (n 62) I35, I53.

75 See also ibid I4O, I52.
} 
the rule of recognition. ${ }^{76}$ As no legal system exists without a rule of recognition, which guarantees the former's normative autonomy, there must be an EU rule of recognition to protect the autonomy thesis. This section aims to show how the ECJ's foundational case law can be understood as providing a normative expression of the rule of recognition.

\section{Van Gend \& Loos as an Internal Recognitional Statement}

If Hart's example of the UK legal system's rule of recognition ('Everything enacted by the Queen in Parliament is law' ${ }^{77}$ is applied by analogy to the EU legal system at the time of van Gend \& Loos, we would get something along the lines of:

All norms of the Treaty of Rome and all norms of secondary legislation enacted in accordance with the Treaty of Rome are valid norms of the EEC legal system (hereinafter: 'RR EEC').

This formulation is quite similar to the ECJ's claims in van Gend \& Loos and Costa $v$ ENEL: 'the Community constitutes a new legal order of international law', ${ }^{8}$ 'the EEC Treaty has created its own legal system', ${ }^{79}$ and, in particular, 'the law stemming from the Treaty [is] an independent source of law'. ${ }^{80}$ What these claims have in common with RR EEC is a seemingly external viewpoint towards the EU Treaties.

At multiple occasions, Hart indeed suggested that the rule of recognition cannot be expressed from the internal point of view, but can only be observed empirically and expressed as an external statement. ${ }^{8 \mathrm{r}}$ Since the rule of

${ }_{76}$ Hart (n I6) 99, II6. I use the term 'central characteristic' as opposed to 'essential' or 'necessary characteristics' because it is doubtful whether Hart regarded the union of primary and secondary rules as 'essential to' or 'necessary for' the concept 'law'. See e.g. Frederick Schauer, 'Hart's Anti-Essentialism' in Andrea Dolcetti, Luis Duarte d'Almeida and James Edwards (eds), Reading HLA Hart's The Concept of Law (Hart 2013).

77 Hart (n I6) IO2.

$7^{8}$ Case 26/62 van Gend \& Loos EU:C:I963:I, I2.

79 Case 6/64 Costa $v$ ENEL EU:C:1964:66, 593.

8o Case 6/64 Costa $v$ ENEL EU:C:1964:66, 594.

${ }_{8 \mathrm{r}} \quad$ E.g.: 'The question of whether a rule of recognition exists and what its content is, i.e. what the criteria of validity in any given legal system are, is regarded 
recognition identifies the law, internal statements of law are rather entailed by the rule of recognition.

Notwithstanding the seemingly external viewpoint expressed by the ECJ in the abovementioned claims, the ECJ's foundational case law does not merely describe some rule of recognition, but takes an explicitly normative approach towards it. Given that the Treaty of Rome has created its own legal system, individuals are allowed to invoke its norms before national courts independently of national law, and national courts are required to apply directly effective norms. The autonomy thesis thus seems to be a normative expression of the rule of recognition.

Whether Hart actually believed that internal, normative statements about the rule of recognition are impossible is unclear. At other times, Hart clearly stated that '[i]n the day-to-day life of a legal system its rule of recognition is very seldom expressly formulated as a rule' and '[f]or the most part the rule of recognition is not stated'. ${ }^{82}$ Focusing on these later statements, Kevin Toh has argued recently that Hart's theory is better understood as allowing for the possibility of what he calls 'internal recognitional statements'. ${ }^{83}$ Internal recognitional statements are formulations of a component of the rule of recognition from an internal point of view. The infrequency with which explicit internal recognitional statements are actually encountered could thus be conceived as a pragmatic phenomenon rather than a conceptual impossibility. ${ }^{84}$ Usually, participants in a legal system will only implicitly express the content of the rule of recognition by applying some first-order norm(s). Moreover, it certainly is not impossible that courts, in exceptional situations, express the content of the rule of recognition explicitly. In Miller, for example, the UK Supreme Court observed that EU law 'derives its legal authority from a statute, which itself derives its authority from the rule of recognition identifying Parliamentary legislation as a source of law'. ${ }^{85}$ The

throughout this book as an empirical, though complex, question of fact' (emphasis added), Hart (n I6) 292.

$82 \quad$ Hart (n I6) IOI.

$83 \quad$ Toh (n 7I) 485 .

${ }^{84}$ For another hypothesis about Hart's ambiguous stance towards internal statements of the rule of recognition: Kevin Toh, 'Four Neglected Prescriptions of Hartian Legal Philosophy' (20I4) 33 Law and Philosophy 689, 699-700. 
rule of recognition can therefore be regarded as having both an external and an internal formulation.

At the time of van Gend \& Loos, we can conceive of the EU legal system's rule of recognition as having the content 'RR EEC'. Today, the rule of recognition might look something like this:

All norms of the Treaty on European Union, the Treaty on the Functioning of the European Union, the Charter of Fundamental Rights of the European Union, and all norms of secondary legislation enacted in accordance with the Treaties and the Charter are valid norms of the EU legal system.

In his discussion on the formulation of the rule of recognition and Hart's distinction between external and internal statements, Toh expresses the logic of the rule of recognition in both an external and an internal statement. ${ }^{86}$ From an external point of view, a rule of recognition then reads as:

We [or: they] actually treat $\mathrm{R}$ as the ultimate criterion of legal validity in this legal system. ${ }^{87}$

As an internal statement, the rule of recognition would read:

We ought to treat $\mathrm{R}$ as the ultimate criterion of legal validity in this legal system!; or

Let us treat $\mathrm{R}$ as the ultimate criterion of legal validity in this legal system. ${ }^{88}$

The ECJ's statements in van Gend \& Loos and Costa $v$ ENEL on the existence of an autonomous EU legal system can similarly be conceptualised as the following internal recognitional statement:

'RR EEC' ought to be treated as the ultimate criteria of legal validity of the EU legal system; or

Let us treat 'RR EEC' as the ultimate criteria of legal validity of the EU legal system.

${ }_{87}$ Ibid. In this regard, by 'R' Toh means any particular (candidate) rule of recognition. 
This conceptualisation of the ECJ's foundational case law not only accounts for the normative formulation of a rule of recognition of an autonomous legal system, but also for the ECJ's attitude towards national courts. Internal (recognitional) statements provide reasons for a certain group of people (for Hart, primarily courts). In other words, internal statements imply a 'reflective critical attitude' on the part of those who follow them, who consider them as a normative standard both for themselves and for others. ${ }^{89}$ In stating that the EU Treaties constitute an autonomous legal system which can be invoked directly before national courts, the ECJ not only accepts this rule of recognition for itself, but also claims that national courts are bound by it. More explicitly than in Costa $v$ ENEL, the Court emphasised the dutyimposing aspect of 'RR EEC' towards national courts in Simmenthal:

It follows from the foregoing that every national court must, in a case within its jurisdiction, apply community law in its entirety and protect rights which the latter confers on individuals and must accordingly set aside any provision of national law which may conflict with it, whether prior or subsequent to the Community rule. ${ }^{90}$

In Toh's formulation of internal recognitional statements, Simmenthal would translate into:

National courts ought to treat 'RR EEC' as the ultimate criteria of legal validity of the EU legal system.

Conceptualising the logic of van Gend $\delta$ Loos and Costa $v$ ENEL as an internal recognitional statement leads to the following interim conclusions. First, the establishment of an autonomous EU legal system takes the form of an internal recognitional statement identifying the Treaty of Rome as an independent source of law, which is reason-giving for its legal officials. Second, this statement claims not only to impose normative duties on the ECJ, but also on the national courts. The national courts are thereby considered 'legal officials' of the EU legal system. Finally, the former conclusions entail that we are able to measure the effectiveness of the EU

89 Hart (n I6) 57: the internal point of view towards rules 'is manifested in the criticism of others and demands for conformity made upon others when deviation is actual or threatened, and in the acknowledgement of the legitimacy of such criticism and demands when received from others'.

90 Case 106/77 Simmenthal EU:C:1978:49, para 21. 
legal system within the Member States. The degree to which EU law is judicially invocable and enforceable before national courts becomes dispositive of whether the EU legal system exists.

\section{Pitching the Rule of Recognition: The Case of General Principles of EU Law}

While internal statements of law presuppose the external statement that the legal system is generally efficacious, ${ }^{91}$ this does not mean that no internal statement can be made which does not yet fully conform to the behaviour of other legal officials. Concluding otherwise would deny the possibility of judicial legal change. Outside their 'normal context', internal statements can also be made to change the content of the rule of recognition:

It will usually be pointless to assess the validity of a rule [...] by reference to rules of recognition [...] which are not accepted by others in fact, or are not likely to be observed in the future..$^{92}$

As Toh puts it, by making a pitch to his interlocutors, a legal official proposing a rule of recognition, or a part of one,

would have to be quite mindful of the existing practices among his fellow community members [...] He would have to tailor his pitches in light of his fellow members' normative opinions and practices if his internal legal statements were to be successful in obtaining the appropriate uptake on their parts. ${ }^{93}$

The partial or total success of the ECJ's autonomy thesis and the doctrines of supremacy and direct effect have been abundantly discussed from the perspective of historical studies and judicial politics. ${ }^{94}$ The motivational

\footnotetext{
9г Hart (n I6) IO4 (emphasis in original).

$92 \quad$ Hart (n 73) I68 (emphasis in original).

$93 \quad$ Toh (n 7I) 499.

94 For historical perspectives, see e.g. Karen Alter, Establishing the Supremacy of European Law (Oxford University Press 200I); Bill Davies, Resisting the ECF: Germany's Confrontation with European Law, 1949-1979 (Oxford University Press 20I2). For judicial politics perspectives, see e.g. Anne-Marie Burley and Walter Mattli, 'Europe Before the Court' (1993) 47 International Organization 4I; Karen Alter, 'The European Court's Political Power' (1996) is West European Politics 452; Tommaso Pavone and R. Daniel Kelemen, 'The Evolving Judicial Politics of European Integration: The European Court of Justice and National Courts Revisited' (2019) 25 European Law Journal 352.
} 
reasons for recognising a source of law and the protected reasons this generates are beyond the scope of this article. Instead, I will try to connect the question of why national authorities would heed the ECJ's pitch for a new rule of recognition to the abovementioned conceptualisation of the autonomy thesis as an internal recognitional statement. As this internal recognitional statement is normative, its normative weight may be salient for the degree of compliance by national authorities. ${ }^{95}$ The development of unwritten general principles of EU law in the ECJ's case law offers a remarkable illustration of how the ECJ aims to adjust the content of EU law's rule of recognition by tailoring its pitches in light of national courts' (likely) normative opinions and practices. ${ }^{96}$

Recognition of certain general principles of law, even where they are not expressly mentioned in the Treaty, may simply reflect the phenomenology of adjudication: in recognising that what they do is interpret the law, judges may commit themselves to recognising particular principles which they also deem central to 'law'.97 An early example is the case Fédération Charbonnière de Belgique, where the ECJ recognised as unwritten principles of EU law the prohibition of misuse of powers and the principle of proportionality..$^{98}$ In his Opinion, AG Lagrange adumbrates both the manner in which the ECJ would later construct the EU legal system and the manner in which the content of

95 I do not want to suggest that the normative weight of the autonomy thesis is the reason for national authorities to apply EU law. My claim is merely that it could be a reason for national authorities to apply EU law. The actual reasons national authorities have for complying with EU law, or even national law, might be very different and diverge widely among judges. There are numerous other examples of how the ECJ's case law could be seen as a pitch towards the national courts for recognising the EU rule of recognition, in particular in areas where the Court balances considerations of effectiveness against the legitimate purposes of national procedural rules. For reasons of space, this section will only discuss general principles.

See Ronald Dworkin's 'The Model of Rules II' and 'Hard Cases', both reprinted in Taking Rights Seriously (Harvard University Press 1978). See also Paul Craig, 'General Principles of Law: Treaty, Historical and Normative Foundations' in Katja Ziegler, Päivi Neuvonen and Violeta Moreno-Lax (eds), Research Handbook on General Principles of EU Law (Edward Elgar 2019). 
the legal system is infused with concepts from national law. The Treaty of Rome is,

from a material point of view, the charter of the Community, since the rules of law which derive from it constitute the internal law of that Community. As regards the sources of that law, there is obviously nothing to prevent them being sought, where appropriate, in international law, but normally and in most cases they will be found rather in the internal law of the various Member States. ${ }^{99}$

Similarly, in Algera the Court was confronted with the question of the revocability of individual rights under the Treaty. As the Treaty did not contain any applicable rules in this regard, the Court observed that

unless the Court is to deny justice it is therefore obliged to solve the problem by reference to the rules acknowledged by the legislation, the learned writing and the case law of the member countries. ${ }^{100}$

While the inclusion of general principles in these cases may simply reflect deep conventions among ECJ judges about what 'law' is, ${ }^{\text {IOI }}$ later case law on the status of fundamental rights as general principles of EU law seemed to involve a more strategic adaptation of the rule of recognition's content. Responding to the Bundesverfassungsgericht's Solange I judgment, ${ }^{102}$ the ECJ maintained the normative supremacy of EU law over all conflicting national law in Internationale Handelsgesellschaft ${ }^{103}$ The proverbial carrot to this stick was the Court's observation that fundamental rights are an inherent part of the EU legal system. The influence of Internationale Handelsgesellschaft

99 Case 8/55 Fédération Charbonnière de Belgique EU:C:1956:6, Opinion of AG Lagrange, 277 (emphasis in original).

100 Joined Cases 7/56, 3/57 to 7/57 Algera EU:C:1957:7, 55 .

ror On the 'deep conventions' of law, see Andrei Marmor, 'Deep Conventions' (2007)

74 Philosophy and Phenomenological Research 586. Deep conventions constitute what counts as a certain social practice. As applied to law, deep conventions are both logically and culturally prior to the rule of recognition, as they determine 'what law in our culture is'. See Andrei Marmor, 'How Law Is Like Chess' in Law in the Age of Pluralism (Oxford University Press 2007) I72-18I, esp I77.

102 BVerfGE 37, 27I, BvL 52/7I (Solange I).

I03 Case II/70 Internationale Handelsgesellschaft EU:C:I970:II4. 
(hereinafter: $I H G$ ), and previously Stauder, ${ }^{\mathrm{IO} 4}$ on the content of the EU rule of recognition can be roughly formulated as follows:

RR EEC before IHG: 'All norms of the Treaty of Rome and all norms of secondary legislation enacted in accordance with the Treaty of Rome are valid norms of the EEC legal system'.

RR EEC after IHG: 'All norms of the Treaty of Rome, unwritten general principles of law including fundamental rights, and all norms of secondary legislation enacted in accordance with the Treaty of Rome, general principles of law and fundamental rights, are valid norms of the EEC legal system'.

It is not difficult to see how this change in the EU rule of recognition strengthens the ECJ's pitch towards national courts: ${ }^{\mathrm{IO5}}$

IHG: 'We ought to treat 'RR EEC after $I H G$ ' as the rule of recognition (don't worry, it guarantees fundamental rights protection)'.

Talk of the 'common constitutional traditions of the Member States', created by the ECJ but now also part of the Treaties, ${ }^{\mathrm{I} 6}{ }^{2}$ signals interaction between the legal system of the Member States and the EU legal order. However, the need for the EU legal system to incorporate fundamental cornerstones of the national legal systems is mostly pragmatic and serves as a credible pitch of the EU's internal recognitional statement.

\section{THE AUTONOMY THESIS AND THE DOCTRINES OF DIRECT EFFECT AND SUPREMACY}

If van Gend \& Loos and Costa $v$ ENEL express the autonomy thesis as an internal recognitional statement, this raises the question what role the doctrines of the direct effect and of supremacy of EU law play within the Hartian framework. This section will respectively translate the two doctrines into a rather crude but consequential rule of adjudication (direct effect), and

\footnotetext{
104 Case 29/69 Stauder EU:C:1969:57, para 7.

ro5 But see Bill Davies, 'Internationale Handelsgesellschaft and the Miscalculation at the Inception of the ECJ's Human Rights Jurisprudence' in Fernanda Nicola and Bill Davies (eds), EU Law Stories (Cambridge University Press 2017).

ro6 E.g. art 6(3) TEU, and arts 67 and 82 TFEU.
} 
a corollary of the normativity of EU law, which lacks self-standing analytical value (supremacy).

\section{A Master Secondary Rule: The Doctrine of Direct Effect}

The existence of an autonomous rule of recognition is constitutive of the existence of an autonomous system of norms. The role of other secondary rules - rules of change and rules of adjudication - then becomes to elaborate further the system's institutional systematicity. Rules of change abound in EU law, as evinced from the numerous legal bases in the Treaties prescribing the creation of EU secondary legislation, ${ }^{107}$ and the procedures for amendment of the Treaty, ${ }^{108}$ accession to the EU, ${ }^{109}$ and exit from the EU. ${ }^{100}$ Rules of adjudication are more elusive. While the adjudicatory competences of the ECJ itself are clearly enumerated in the Treaties, ${ }^{\text {III }}$ the same is not true for national courts. The latter's competences draw largely from national law. Direct effect of EU law, however, plays a crucial role here.

Direct effect has had several meanings in the ECJ's case law and legal scholarship. It has been referred to as the principle which essentially brings EU norms into the national legal orders. ${ }^{112}$ The autonomy thesis leaves no room for an incorporation mechanism of that sort. If the EU legal system is an autonomous legal system, national courts (and other national (administrative) authorities) must be members of the EU legal system, i.e. they must 'count as' EU courts when they apply EU law. ${ }^{\mathrm{II}}$

A more important and consequential dimension of direct effect is the invocability of sufficiently precise and unconditional EU norms before national courts. The right to invoke EU norms is essentially a rule of adjudication, which grants national courts the competence to apply norms of

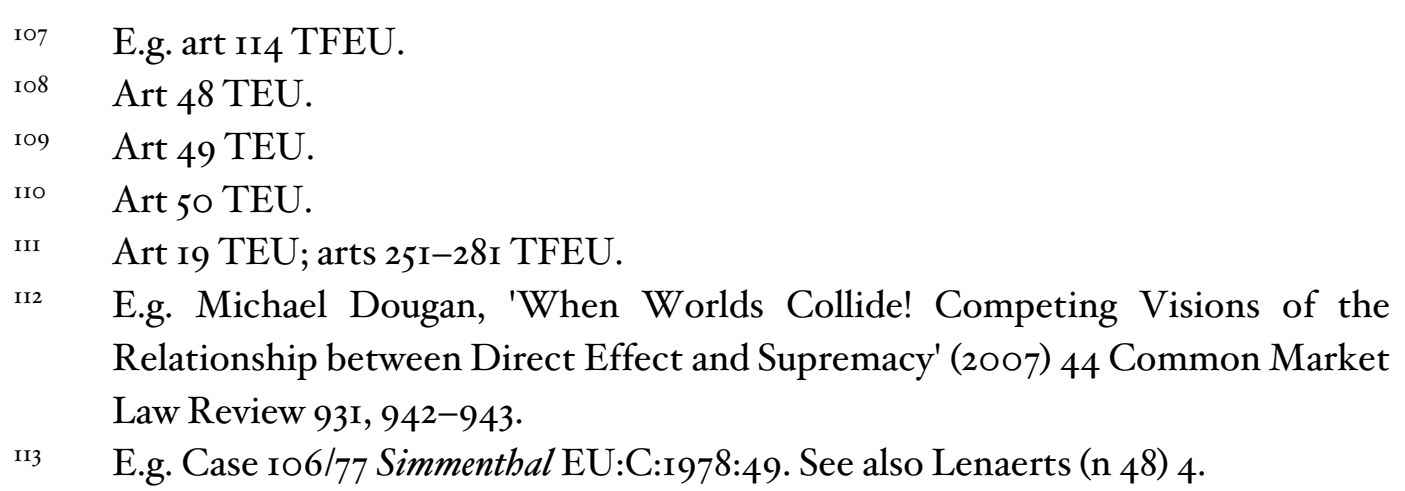


EU law. In more recent cases, the ECJ explicated this rule of adjudication by characterising direct effect as an obligation on national courts and national administrative authorities to apply the EU norms invoked before them. ${ }^{\mathrm{I}} 4$ The rule of adjudication seems almost a corollary of the internal formulation of the rule of recognition. By identifying a source of law that national courts qua EU officials ought to apply, one cannot at the same time deny those courts the competence to apply that source of law. In this sense, direct effect qua rule of adjudication is a more specific expression of the internal formulation of the rule of recognition. In van Gend \& Loos, only after proclaiming the autonomy of EU law does the Court move on to the practical implication of this autonomy thesis, i.e. the doctrine of direct effect. In one masterful stroke, direct effect grants all national courts the competence to apply EU law norms. ${ }^{\mathrm{II}}$

This competence is, of course, limited by national procedural rules. ${ }^{\mathrm{II} 6}$ Procedural law is also part of the set of rules of adjudication. ${ }^{117}$ Whether EU norms can be invoked before national courts, and whether national courts are allowed or obligated to apply them, flows from a complex interaction between EU and national law. However, the ability to invoke EU law norms and the obligation on national courts to apply them subsequently is always

${ }_{114}$ E.g. Case 103/88 Fratelli Costanzo EU:C:I989:256, para 31; Case C-201/O2 Wells EU:C:2O04:I2, paras 64-65. See further Sacha Prechal, 'Does Direct Effect Still Matter?' (2000) 37 Common Market Law Review I047.

II5 In this sense, direct effect is indeed the 'normal state of the law' and its relevance as a separate doctrine is limited. On broader questions on the limits to invocability of EU law see Koen Lenaerts and Tim Corthaut, 'Towards an Internally Consistent Doctrine on Invoking Norms of EU Law' in Sacha Prechal and Bert van Roermund (eds), The Coherence of EU Law (Oxford University Press 2008); and Lorenzo Squintani and Justin Lindeboom, 'The Normative Impact of Invoking Directives: Casting Light on Direct Effect and the Elusive Distinction between Direct Obligations and Mere Adverse Repercussions' (2019) 38 Yearbook of European Law i8.

II6 On the role of national procedural rules from the perspective of EU law, see section III.I. above.

II7 Hart (n I6) 97: 'Besides identifying the individuals who are to adjudicate, [rules of adjudication] will also define the procedure to be followed'. 
the default position. ${ }^{\mathrm{II} 8}$ Furthermore, from the perspective of EU law, arguably these national rules serve as ancillary EU law. In Kakouris's words:

Thus, because recourse to national procedural law has been in order to fill a gap in Community law, this law is subordinated to Community law and must, where necessary, be altered in order to fulfil its ancillary function [to ensure the effective application of substantive Community law]. ${ }^{119}$

Hence, national procedural rules are woven into the default position enshrined in the doctrine of direct effect. In other words, EU law uses national procedural law to pursue the effective enforcement of EU substantive law. In doing so, these national rules are dissociated from their national legal system and become part of EU law. ${ }^{\text {I20 }}$ Such would, at least, be the viewpoint of the EU legal system if it had to justify the logic of what is going on - and of course if it could speak. ${ }^{\mathrm{I} 2 \mathrm{I}}$

Kakouris emphasises in this regard that national courts, when applying EU law, 'belong from the functional point of view to the Community legal order'. ${ }^{22}$ The functional perspective will not suffice, however, as regards the status of national procedural rules. National procedural rules cannot be an ancillary part of the EU legal system only because national courts qua EU courts happen to apply them: they must be validated themselves in some way by the EU legal system. ${ }^{\mathrm{I} 3}$ It appears, however, that from the perspective of EU law, all national procedural rules which do not violate the principles of equivalence and effectiveness are validated as EU law norms by the doctrine of direct effect and the principle of sincere cooperation in article 4(3) TEU

Ir8 For a clear illustration, Case C-453/99 Courage v Crehan EU:C:200I:465, paras 243 I.

ı9 CN Kakouris, 'Do the Member States Possess Judicial Procedural "Autonomy"?' (1997) 34 Common Market Law Review I389, 1396.

I20 Ibid I4O4: 'in the absence of Community procedural law, the national courts apply the national rules of procedural law, which thus become ancillary Community law' (emphasis added).

${ }^{\mathrm{I} 2 \mathrm{I}}$ See $\mathrm{n}$ 22. On the law as a 'subject', see Alexander Somek, The Legal Relation (Cambridge University Press 2017) 87-92.

${ }_{122}$ Kakouris (n II9) I393-I394.

${ }^{123}$ I owe this point to Boško Tripković. 
qua rule of adjudication. This rule of adjudication could logically be rephrased along these lines:

National courts ought to apply justiciable norms of EU law, within the constraints of the procedural rules as laid down in applicable national procedural law insofar as the latter comply with the principles of equivalence and effectiveness.

Consequently, the validation of national procedural rules as EU norms could be grounded in EU law, giving them binding effect within the EU legal system. The process of giving binding effect to extra-legal norms is indeed pervasive in legal systems. ${ }^{\mathrm{I} 4}$

\section{Taking Norms Seriously: The Doctrine of Supremacy}

The supremacy of EU law is usually portrayed as a 'principle' or a '(conflict) rule', which belongs to the positive norms of EU law. Some authors distinguish between 'primacy' and 'supremacy'. ${ }^{125}$ According to Avbelj, for instance, primacy is 'a trans-systemic principle, which regulates the relationship between the autonomous legal orders', while supremacy is rather 'the feature of supreme legal acts in the legal orders of the Member States and of the EU; [...] an intra-systemic feature'. ${ }^{126}$ Schütze seems to have something slightly different in mind when he refers to supremacy as 'the superior hierarchical status of the Community legal order over the national legal

${ }^{124}$ See Joseph Raz, Practical Reason and Norms (Clarendon Press 1975) 15I-154; and as applied to EU law, Lindeboom (n I3) 346-348, referring to other examples including art 6(3) TEU and art 52(3) CFR. Something similar happens in EU internal market law when a national measure derogates from a fundamental freedom. This measure is then considered to 'implement EU law' in the sense of art 5I(I) CFR. Thus, from the perspective of EU law, such a national measure becomes in a way part of the EU legal system. See Koen Lenaerts and José Gutiérrez-Fons, 'The EU Internal Market and the EU Charter: Exploring the "Derogation Situation"' in Fabian Amtenbrink, Gareth Davies, Dimitry Kochenov and Justin Lindeboom (eds), The Internal Market and the Future of European Integration (Cambridge University Press 2019).

${ }^{125}$ See Matej Avbelj, 'Supremacy or Primacy of EU Law - (Why) Does it Matter?' (2OII) I7 European Law Journal 744, with further references.

I26 Ibid 750. 
orders'. ${ }^{27}$ Others have noted that EU law only claims primacy rather than supremacy, because it does not invalidate conflicting national law. ${ }^{\mathrm{I} 28}$

The autonomy thesis makes this distinction redundant and translates supremacy into a truism of the legal system. ${ }^{\text {I29 }}$ Primacy as a trans-systemic principle, on the other hand, presupposes normative interaction between legal orders as a whole. But the autonomous nature of legal systems makes discussing the normative superiority of legal orders legally irrelevant. ${ }^{130}$ After all, any meaningful legal relationship between legal systems - manifested by some conflict rule, regardless of how it is called - immediately subsumes those supposedly autonomous legal systems to an overarching legal system which is supreme. In absence of a way for legal systems to legally relate to each other, the only legal hierarchy left is within each system, again obfuscating any distinction between primacy and supremacy. To put this in Hartian terminology, questions of legal hierarchy and legal-normative conflict between legal systems are irrelevant because legal systems exist as such only by virtue of a certain rule of recognition. This is precisely what autonomy is all about.

At a practical level, the application of legal norms by legal officials depends on whether these officials are committed to (some part of) the rule of recognition identifying these norms as legally valid. Any application of an EU norm is an implicit commitment to at least the relevant part of an internal recognitional statement. When legal officials recognise more than one legal

${ }^{27}$ Robert Schütze, 'Supremacy without Pre-emption? The Very Slowly Emergent Doctrine of Community Pre-emption' (2006) 43 Common Market Law Review IO23, IO33 (emphasis in original).

ז28 Joined Cases C-Io/97 to C-22/97 IN.CO.GE.'9o EU:C:I998:498, para 21; Monica Claes, 'The Primacy of EU Law in European and National Law' in Damian Chalmers and Anthony Arnull (eds), The Oxford Handbook of European Union Law (Oxford University Press 2015) I82.

I29 Lindeboom (n I3).

r30 See also MacCormick (n I9). Admittedly, the result is a cynical conception of legal normativity: Gunther Teubner, 'The King's Many Bodies: The SelfDeconstruction of Law's Hierarchy' (1997) 31 Law \& Society Review 763, 782-784. 
system, the resolution of any conflict between them is simply a choice between the concurrent rules of recognition in individual cases. ${ }^{13 \mathrm{I}}$

Since the supremacy claim only applies within the system, it would be mistaken to conceive of the autonomy thesis as 'EU-centred monism'. ${ }^{132}$ The ECJ has never claimed that national legal systems are subsumed under the EU legal system. Such a view would presumably also imply that national laws conflicting with EU law are invalid in virtue of EU law, or at least could be declared invalid on the basis of EU law, positions both of which the ECJ notwithstanding obscure allusions in Costa $v$ ENEL - has not further pursued. ${ }^{133}$ By contrast, the autonomy thesis is not troubled by the fact that EU law does not claim to entail the invalidation of conflicting national law. As the EU legal system has no hierarchical connection with national legal systems, it is nonsensical to speak of invalidation in this context.

The doctrine of supremacy, then, is merely a doctrinal conceptualisation of EU law's claim to be robustly normative, ${ }^{134}$ and to provide reasons for action which also exclude reasons for acting otherwise - for instance, national laws allowing something which EU law prohibits - from the balance of reasons. ${ }^{135}$ This may well be part of our concept of law, which seems infused with the notion of supremacy over concurrent normative systems, possibly rooted in

I3I See also Gareth Davies, 'Constitutional Disagreement in Europe and the Search for Pluralism' in Jan Komárek and Matej Avbelj (eds), Constitutional Pluralism in the European Union and Beyond (Hart 2012); Barber (n 18 ).

${ }^{132}$ Cf. Eleftheriadis, 'Pluralism and Integrity' (n 20).

133 Case 6/64 Costa v ENEL EU:C:1964:66, 592-593, referring to the context of (now) art 258 TFEU; Joined Cases C-Io/97 to C-22/97 IN.CO.GE.'9o EU:C:I998:498, para 2I.

134 Robust normativity indicates that the respective norms give genuine rather than formal reasons for action: they prescribe what we really ought to do. The normativity of a game is usually taken to be an example of formal normativity. According to many legal philosophers, all legal systems claim to be robustly normative. Whether law is as robustly normative as it claims is contested. Compare e.g. David Enoch, 'Is General Jurisprudence Interesting?', with George Letsas, 'How to Argue for Law's Full-Blooded Normativity', both in David Plunkett, Scott Shapiro and Kevin Toh (eds), Dimensions of Normativity (Oxford University Press 2019).

I35 I.e. 'protected reasons', as Raz calls them in $\operatorname{Raz}$ (n 53) I7ff. 
our association between law and the sovereign state. ${ }^{136}$ Costa $v$ ENEL appears to point to the conceptual connection between law and supremacy: ${ }^{137}$

[T]he law stemming from the Treaty, an independent source of law, could not, because of its special and original nature, be overridden by domestic legal provisions, however framed, without being deprived of its character as Community law. ${ }^{138}$

\section{Some Preliminary Remarks About Perspectivism and National Courts}

The previous discussion on the (ir)relevance of direct effect and supremacy as self-standing doctrines of law links to the longstanding discussion on the competing supremacy claims by national and EU legal systems and their respective apex courts. According to a common and well-known objection against the ECJ's foundational case law, national legal officials only apply EU law because their respective national legal systems obligate them to do so. ${ }^{139}$ Indeed, having established a rational explanation of the ECJ's foundational case law does not obviate the question of whether the behaviour, attitudes and perspectivism of national courts - in particular national constitutional courts $^{\mathrm{IO}}$ - threatens the theoretical and empirical correctness of the autonomy thesis.

136 Andrei Marmor, Positive Law and Objective Values (Oxford University Press 200I) 39-42.

${ }^{137}$ Elsewhere I have argued that the conceptual connection between law and supremacy in Costa $v$ ENEL can also be understood as reflecting a 'Hamiltonian' conception of supremacy, following Alexander Hamilton's conception of the US federal order in The Federalist No 27 and No 33. See Justin Lindeboom, 'Is the Primacy of EU Law Based on the Equality of the Member States? A Comment on the CJEU's Press Release Following the PSPP Judgment' (2O20) 2I German Law Journal IO32.

138 Case 6/64 Costa v ENEL EU:C:1964:66, 594 (emphasis added).

139 E.g. Michael Giudice, 'Conceptual Analysis, Legal Pluralism, and EU Law' (2015) 6 Transnational Legal Theory 586.

I40 For well-known examples, see e.g. BVerfGE 123, 267, 2 BvE 2/o8 (2009); Czech Constitutional Court, Case Pl ÚS 50/04 (2006); Conseil d'état, Case No. 2265I4 (200I); Italian Constitutional Court, Case No I83/1973 (1973); and Polish Constitutional Court, Decision K I8/04 (2005). See, most recently, BVerfG, 2 BvR 859/15, ECLI:DE:BVerfG:2O2O:rs20200505.2bvro85915 (2020) on the ECB's 
However, a legal-theoretical analysis of the salience of the psychological attitudes of national judges, and their reasons for and acts of applying EU law, entails deeply contested questions of analytical jurisprudence. For one, Toh claims that what judges believe to be their rule of recognition is categorically distinct from what is the rule of recognition. ${ }^{4 \mathrm{I}}$ The correctness of any claim of the latter kind would require normative reasoning, to the extent that there might be a rule that is the real rule of recognition of that community 'despite the lack of common recognition or acceptance of it, by the community's members or officials, as the community's rule of recognition'. ${ }^{122}$ Along these lines, it might be that national (constitutional) courts which do not treat the EU rule of recognition as the rule of recognition might simply be mistaken. ${ }^{143}$ Put differently, whether or not EU law is an autonomous legal system, such does not depend on the fact that some, many, or all national courts treat the binding force of EU law as being rooted in their own constitutions. ${ }^{\text {I44 }}$

Even if one considers the 'mainstream' position in Anglo-American legal positivism, according to which the existence and content of law is ultimately

Public Sector Asset Purchase Programme (PSPP) and the ECJ's judgment in Case C-493/17 Weiss EU:C:2018:100o.

I4r Toh (n 7r); Kevin Toh, 'Legal Philsophy à la carte' in David Plunkett, Scott Shapiro and Kevin Toh (eds), Dimensions of Normativity (Oxford University Press 2019) $235-238$.

${ }_{142}$ Toh (n I4I) 237. This conclusion appears at odds with the Hartian project, but instead is based on Dworkinian conceptions of legality. However, Toh argues that Hart endorsed the so-called 'social fact' thesis only in relation to the external point of view. I find this a plausible reading of Hart's theory of law.

I43 Such a theory of the existence and content of the (real) rule of recognition, whether based on Hartian or Dworkinian grounds, would of course have to include some criteria to identify the rule of recognition other than the beliefs or behaviour of judges as matters of social fact. Toh suggests applying the method of reflective equilibrium by 'arguing for particular rules as making up [a community's] rule of recognition by showing that these rules do a better job of meshing with considered legal judgments than any alternative candidates for components of the rule of recognition' (Toh (n I4I) 237).

I44 I am thankful to Kevin Toh for raising this point, although I put it in slightly different terms. 
a matter of social fact only, ${ }^{\mathrm{I} 5}$ and disputes about the rule of recognition can be solved by a head-count among the relevant category of legal officials, ${ }^{146}$ the salience of national (constitutional) courts' opinions is obscure. Hart emphasised, for instance, that the internal point of view is not about the 'feeling', 'emotion' or 'special psychological experience' of officials. ${ }^{147}$ Making an internal statement of law is an 'act of recognition': in expressing the content of the rule, that rule is recognised as a standard for behaviour and a reason for criticising departure from that standard. ${ }^{14^{8}}$ Outside incidental instances of reference to ultimate standards of legality - which are usually confined to the jurisprudence of national constitutional courts - most applications of EU law by national courts leave open the ultimate criteria of validity. ${ }^{\text {I49 }}$ It might be that the prevalence of national courts' applications of EU law - even in the absence of a sufficiently prevalent moral endorsement on their part of some autonomous EU rule of recognition - suffices to corroborate the correctness of the autonomy thesis. ${ }^{50}$

As I mentioned above, a full analysis of the salience of the perspectivism of national courts cannot be discussed here, and consequently I shall have to defer such analysis to another occasion. Whether national courts can be mistaken about their own identity as legal officials is only one of many complex questions remaining. However, these and other questions do require, for a start, a rational and theoretically sustainable explanation of the ECJ's autonomy thesis. By employing Hartian legal theory and the post-

I45 See e.g. Raz (n 53) 47-48; Gerald Postema, 'Coordination and Convention at the Foundations of Law' (1982) ir Journal of Legal Studies I65; Scott Shapiro, Legality (Harvard University Press 2OII) 44, 200-20I.

I46 Brian Leiter, 'Explaining Theoretical Disagreement' (2009) 76 University of Chicago Law Review I215, 1222.

I47 Hart (n 73) I66.

I48 Ibid I65-I66.

I49 It is recalled that in any legal system 'Lf]or the most part the rule of recognition is not stated' (Hart (n I6) IoI).

150 Raz famously pointed out the importance in legal discourse of 'detached legal statements', i.e. statements of law which do not express endorsement of the law, but merely prescribe the content of the law from a 'detached' point of view. Legal officials can state what the law requires, just as a Catholic, who happens to be an expert in Rabbinical law, can state what the latter requires of an orthodox but relatively ill-informed Jew who asks for advice ( $\operatorname{Raz}(\mathrm{n} 53)$ I56-157). 
Hartian notion of 'internal recognitional statements', this article has aimed to provide such an explanation.

\section{CONCLUSION}

Among the numerous normative systems upheld, communities are governed by legal systems when a certain subset of their members recognise a normative system comprising both primary and secondary norms, which is united by a law-identifying 'rule of recognition'. This Hartian theory of law elucidates the question what it means to say that EU law is an autonomous legal system. From a Hartian perspective, legal systems are autonomous in the sense that they have their own rules of recognition. ${ }^{15 \mathrm{I}}$ It is clear that such a rule of recognition can be formulated for the EU legal system. More importantly, what I have tried to show is that the ECJ's foundational case law on autonomy, direct effect and supremacy can be conceptualised as internal statements referencing this rule of recognition. We should therefore be comfortable in recognising the EU legal system's autonomy, even if we do not normatively endorse it, ${ }^{152}$ or if we consider the ECJ's hermeneutics illegitimate. ${ }^{153}$

The autonomy of EU law is intrinsically connected to its effectiveness: there would be no EU legal system if no one applied it. It is absolutely crucial, however, that effectiveness cannot be the reason for autonomy, just as it cannot be the reason for legal validity. Rather, as I have tried to show, the ECJ's reliance on effectiveness to justify the autonomy of EU law indicates that internal statements of law presuppose a general context of effective enforcement, or at least the prediction that this effectiveness will materialise.

${ }^{151}$ Recent debate on 'inclusive' and 'exclusive' variants of Hartian legal positivism centres on the autonomy of the content of legal systems and the rule of recognition. I leave this debate aside because it presupposes that at least there are rules of recognition and that they are autonomous in the sense that they alone - rather than any other written or unwritten rules - indicate the criteria of legality.

152 Alexander Somek, 'Inexplicable Law: Legality's Adventure in Europe' in Nico Stehr and Bernd Weiler (eds), Who Owns Knowledge?: Knowledge and the Law (Routledge 20I7).

${ }_{153}$ Somek (n 23); Stone Sweet (n 27). 
Thus, the Court's proclamation of the autonomy thesis amounts to the creation of an internal point of view for itself, which goes hand-in-hand with its invitation to the national courts to join. Once we recognise the autonomy thesis as an internal recognitional statement which purports to achieve national courts' uptake by way of a 'normative pitch', we can ditch confused talk about the 'incorporation' of EU law into national legal systems and quasi-Kelsenian conundrums of normative hierarchy between legal systems. Were the EU legal system able to read Hart's The Concept of Law, it would likely recognise itself. 